\title{
High-Quality ZnCdS Nanosheets Prepared Using Solvothermal Synthesis
}

\author{
M. A. Mahdi, ${ }^{1}$ J. J. Hassan, ${ }^{1}$ S. S. Ng, $^{2}$ and Z. Hassan ${ }^{2}$ \\ ${ }^{1}$ Basrah Nanomaterials Research Group (BNRG), Department of Physics, College of Science, University of Basrah, \\ Basrah 61004, Iraq \\ ${ }^{2}$ Nano-Optoelectronics Research and Technology Laboratory (NOR), School of Physics, Universiti Sains Malaysia, \\ 11800 Penang, Malaysia
}

Correspondence should be addressed to M. A. Mahdi; mazinauny74@yahoo.com

Received 30 March 2013; Accepted 7 June 2013

Academic Editor: Mingwang Shao

Copyright (C) 2013 M. A. Mahdi et al. This is an open access article distributed under the Creative Commons Attribution License, which permits unrestricted use, distribution, and reproduction in any medium, provided the original work is properly cited.

For the first time, $\mathrm{Zn}_{x} \mathrm{Cd}_{1-x} \mathrm{~S}$ nanosheets with different $\mathrm{Zn}$ and $\mathrm{Cd}$ ion concentrations were prepared using solvothermal synthesis at $200^{\circ} \mathrm{C}$ for 4 and $24 \mathrm{~h}$. The crystalline structure of the nanosheets was wurtzite. The optical band gaps of the nanosheets increased with increasing $\mathrm{Zn}$ ratio; this increase is consistent with the band gaps estimated using Vegard's formula. The photoluminescence spectra for the $24 \mathrm{~h}$ nanosheets had higher emission intensities than those for the $4 \mathrm{~h}$ nanosheets. The emission band corresponding to intrinsic near-band-edge emission and a broad peak associated with extrinsic deep-level emission were observed in the photoluminescence spectra.

\section{Introduction}

One-dimensional (1D) semiconductor nanostructures have recently become widely used because of their special properties: quantum confinement, high surface-to-volume ratio, high optical gain, fast response, and specific crystalline orientation [1-3]. Ternary II-VI semiconductor materials have attracted more interest than binary compounds because some of their properties, such as their tunable optical properties, are better than those of binary compounds. The tunable optical properties of ternary II-VI semiconductor materials can be controlled by appropriately adjusting the constituent mole fractions, particle sizes, and morphologies of the materials [4]. Thus, the formation of $\mathrm{Zn}_{x} \mathrm{Cd}_{1-x} \mathrm{~S}$ led to the control of the optical band gap in a range of ternary phases for $\mathrm{CdS}(2.42 \mathrm{eV})$ and $\mathrm{ZnS}(3.77 \mathrm{eV})[5$, 6]. $\mathrm{Zn}_{x} \mathrm{Cd}_{1-x} \mathrm{~S}$ nanocrystalline structures can be obtained using various chemical and physical methods [5, 7-11]. Among the chemical methods, solvothermal synthesis has received considerable attention because of the possibility of preparing high-crystallinity $1 \mathrm{D}$ nanostructured materials. Preparation of nanosized metal grids by using lithography led to the fabrication of many types of devices based on single wires, ribbons, belts, and sheets [12-15]. Single $1 \mathrm{D}$ nanostructured devices are more efficient and perform better than optoelectronic and gas sensor devices based on thin films [15]. The solvothermal method can produce high-purity nanocrystalline materials with a high degree of crystallinity compared with other solution-based methods [16]. Herein, the $\mathrm{Zn}_{x} \mathrm{Cd}_{1-x} \mathrm{~S}$ nanosheets were synthesized for the first time via the solvothermal method. The effect that reaction time and $\mathrm{Zn}$ ratio had on the morphologies, crystalline structures, and optical properties of the nanosheets was investigated.

\section{Experimental Section}

Cadmium chloride $\left(\mathrm{CdCl}_{2}\right)$, zinc chloride $\left(\mathrm{ZnCl}_{2}\right)$, and sulfur (S) powders were used as $\mathrm{Cd}^{2+}, \mathrm{Zn}^{2+}$, and $\mathrm{S}^{2-}$ ions sources, respectively. The powders were dissolved in $50 \mathrm{~mL}$ of ethylenediamine (en) and were stirred for $10 \mathrm{~min}$. The solution was poured into a $100 \mathrm{~mL}$ Teflon-lined stainless steel autoclave filled with en to $70 \%$ of its total volume. The autoclave was sealed and subsequently loaded into an oven. Four nanocrystalline samples were prepared at $200^{\circ} \mathrm{C}$ for 4 and $24 \mathrm{~h}$ with different ion source concentrations, as 
TABLE 1: $\mathrm{Zn}_{x} \mathrm{Cd}_{1-x} \mathrm{~S}$ nanosheets preparation parameters, $\mathrm{Zn}$ ratio in the compounds, and optical band gap values.

\begin{tabular}{lcccccc}
\hline $\begin{array}{l}\mathrm{CdCl}_{2} \text { concentration } \\
(\mathrm{gm})\end{array}$ & $\begin{array}{c}\mathrm{ZnCl}_{2} \\
\text { concentration }(\mathrm{gm})\end{array}$ & $\begin{array}{c}\text { Duration time } \\
(\mathrm{h})\end{array}$ & $\begin{array}{c}\mathrm{Zn} \text { ratio } \\
(\%)\end{array}$ & Compound & $\begin{array}{c}\text { Calculated } E_{g} \\
(\mathrm{eV})\end{array}$ & $\begin{array}{c}E_{g} \text { estimated from } \\
\text { Vegards' formula } \\
(\mathrm{eV})\end{array}$ \\
\hline 0.1 & 0.1 & 4 & 0.34 & $\mathrm{Zn}_{0.34} \mathrm{Cd}_{0.66} \mathrm{~S}$ & 2.70 & 2.72 \\
0.03 & 0.22 & 4 & 0.81 & $\mathrm{Zn}_{0.81} \mathrm{Cd}_{0.19} \mathrm{~S}$ & 3.42 & 3.38 \\
0.03 & 0.12 & 24 & 0.7 & $\mathrm{Zn}_{0.70} \mathrm{Cd}_{0.30} \mathrm{~S}$ & 3.27 & 3.20 \\
0.1 & 0.22 & 24 & 0.88 & $\mathrm{Zn}_{0.88} \mathrm{Cd}_{0.12} \mathrm{~S}$ & 3.54 & 3.50 \\
\hline
\end{tabular}

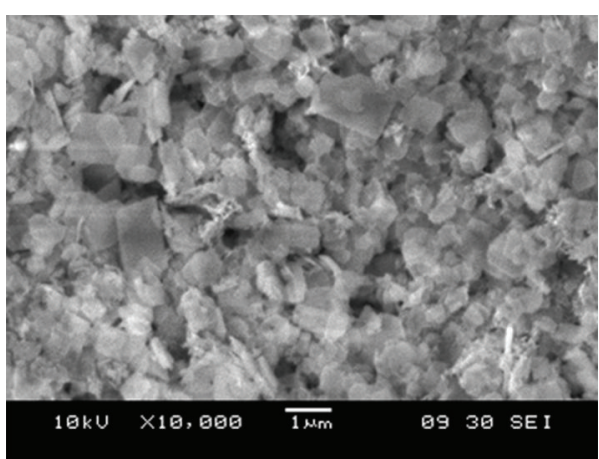

(a)

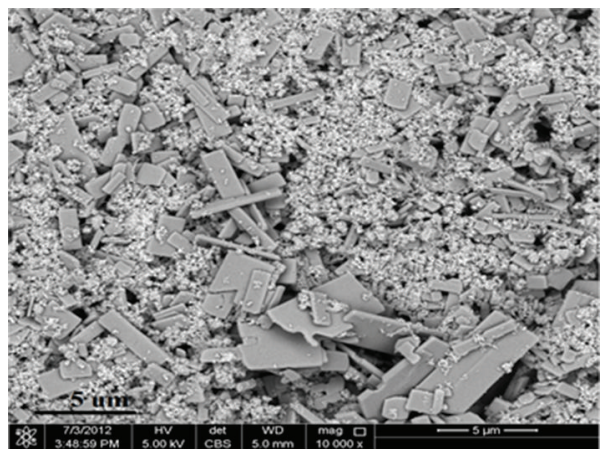

(c)

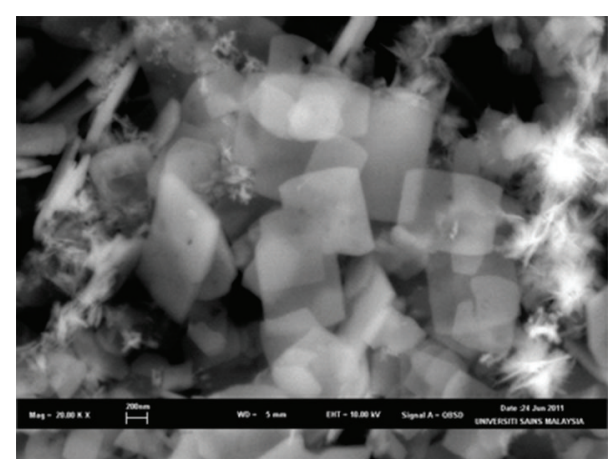

(b)

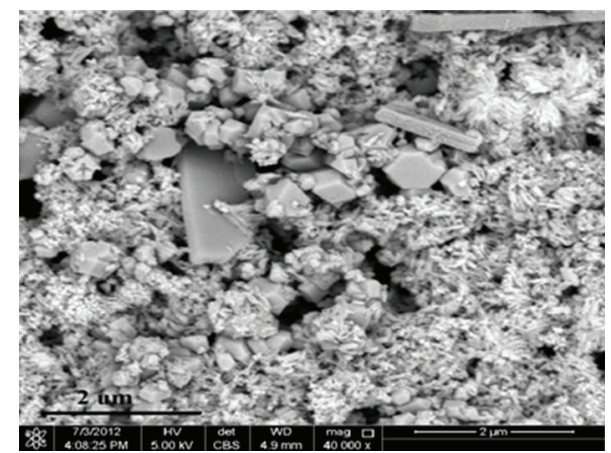

(d)

Figure 1: FESEM images of ((a) and (b)) $4 \mathrm{~h} \mathrm{Zn}_{0.34} \mathrm{Cd}_{0.66} \mathrm{~S}$ and $\mathrm{Zn}_{0.81} \mathrm{Cd}_{0.19} \mathrm{~S}$ nanosheets, ((c) and (d)) $24 \mathrm{~h} \mathrm{Zn}_{0.7} \mathrm{Cd}_{0.3} \mathrm{~S}$ and $\mathrm{Zn}_{0.88} \mathrm{Cd}{ }_{0.12} \mathrm{~S}$ nanosheets.

summarized in Table 1. After the samples were prepared, the autoclave was removed from the oven and cooled naturally. The resulting precipitates were filtered, washed several times with absolute ethanol and with distilled water, and air-dried at $60^{\circ} \mathrm{C}$ for $2 \mathrm{~h}$. Field-emission scanning electron microscopy (FE-SEM, FEI Nova NanoSEM 450) was used to determine the morphologies of the products. Quantitative elemental analysis was performed using an energy dispersive spectrometer (EDS) attached to the FE-SEM equipment. The crystalline structure of the prepared $\mathrm{ZnCdS}$ nanostructures was investigated using X-ray diffraction (XRD, PANalytical X'Pert PRO MRD PW3040) with CuK $\alpha$ radiation. Optical absorption and photoluminescence (PL) were measured using a Shimadzu UV-vis spectrophotometer (UV-1800) and Horiba Jobin Yvon H 800 UV equipment.

\section{Results and Discussions}

Figure 1 shows the FE-SEM images of the samples prepared at $200^{\circ} \mathrm{C}$ for 4 and $24 \mathrm{~h}$ with different $\mathrm{Zn}$ and $\mathrm{Cd}$ source ion concentrations. The $\mathrm{Zn}_{x} \mathrm{Cd}_{1-x} \mathrm{~S}$ formed nanosheets when the preparation time was $4 \mathrm{~h}$ for different ion concentrations. The nanosheet dimensions increased when the preparation time was increased to $24 \mathrm{~h}$, as shown in Figures $1(\mathrm{c})$ and 1(d), indicating that the sheets grew in length, width, and thickness. Nanoparticles and nanorods were also formed in the $24 \mathrm{~h}$ samples. In solvothermal synthesis, solvent type plays an important role in the formation of nanocrystalline materials, especially in determining their structural type. One of the most commonly used solvents to produce nanocrystalline structures is ethylenediamine en $\left(\mathrm{H}_{2} \mathrm{NCH}_{2} \mathrm{CH}_{2} \mathrm{NH}_{2}\right)$ 


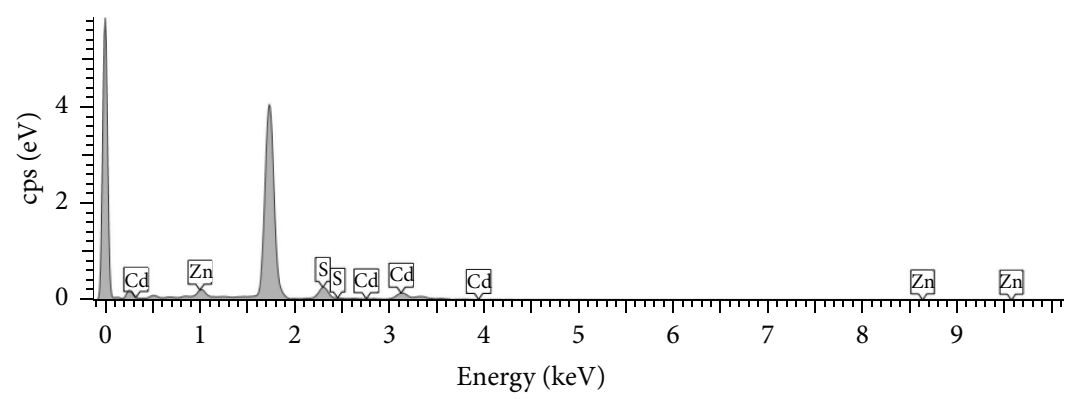

(a)

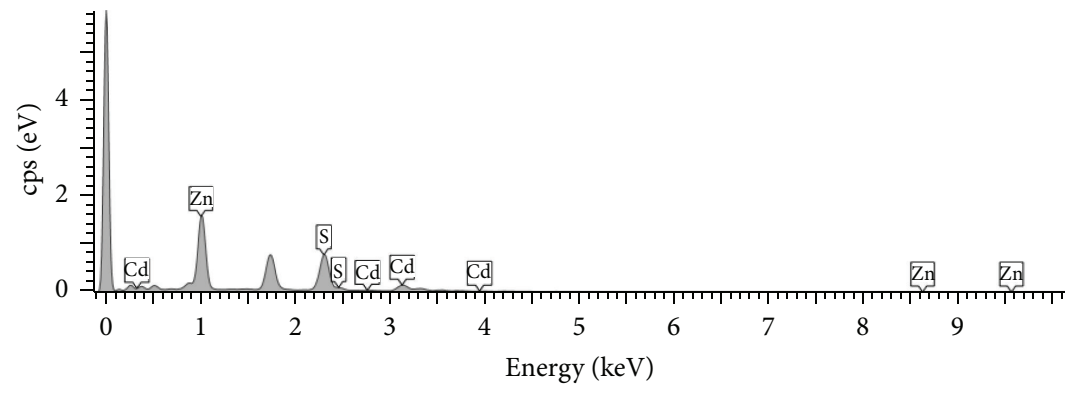

(b)

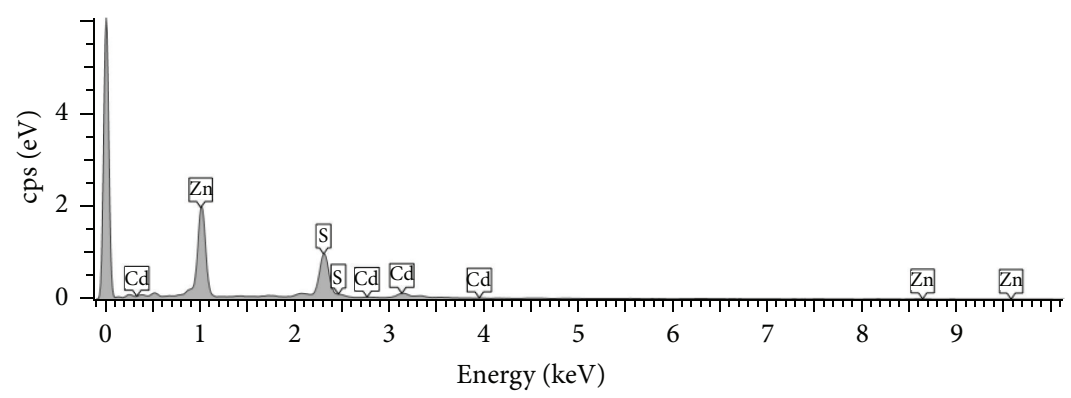

(c)

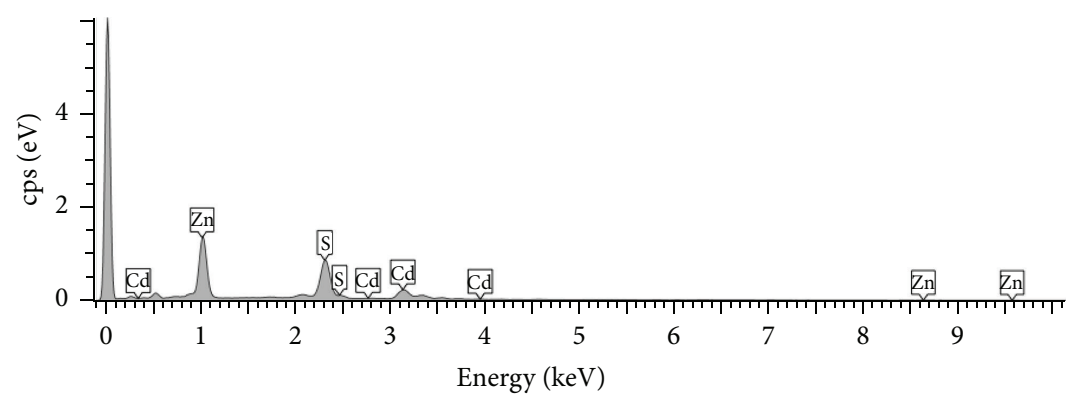

(d)

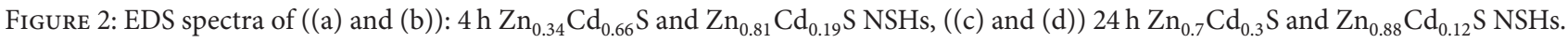

because of its low dielectric constant (13.82 at room temperature) and boiling point $\left(116^{\circ} \mathrm{C}\right)$. It simultaneously acts as a solvent and complexing agent. First, cadmium and zinc ions interact with the lone pair electrons of the en nitrogen atoms to form a $\left[\mathrm{Zn}_{x} \mathrm{Cd}_{1-x}(\mathrm{en})_{2}\right]^{2+}$ complex. Then, the $\left[\mathrm{Zn}_{x} \mathrm{Cd}_{1-x}(\mathrm{en})_{2}\right]^{2+}$ complex then reacts with sulfur ions, generated slowly in the solution, to form a two-dimensional
(2D) $\mathrm{Zn}_{x} \mathrm{Cd}_{1-x} \mathrm{~S}-0.5 \mathrm{en}$ complex, as shown in the following reactions:

$$
\begin{aligned}
x \mathrm{Zn}^{2+}+(1-x) \mathrm{Cd}^{2+}+2 \mathrm{en} & \longrightarrow\left[\mathrm{Zn}_{x} \mathrm{Cd}_{1-x}(\mathrm{en})_{2}\right]^{2+} \\
{\left[\mathrm{Zn}_{x} \mathrm{Cd}_{1-x}(\mathrm{en})_{2}\right]^{2+}+\mathrm{S}^{2-} } & \longrightarrow \mathrm{Zn}_{x} \mathrm{CdS}_{1-x} \cdot 0.5(\mathrm{en}) \\
& \longrightarrow \mathrm{Zn}_{x} \mathrm{Cd}_{1-x} \mathrm{~S}+\text { en }
\end{aligned}
$$




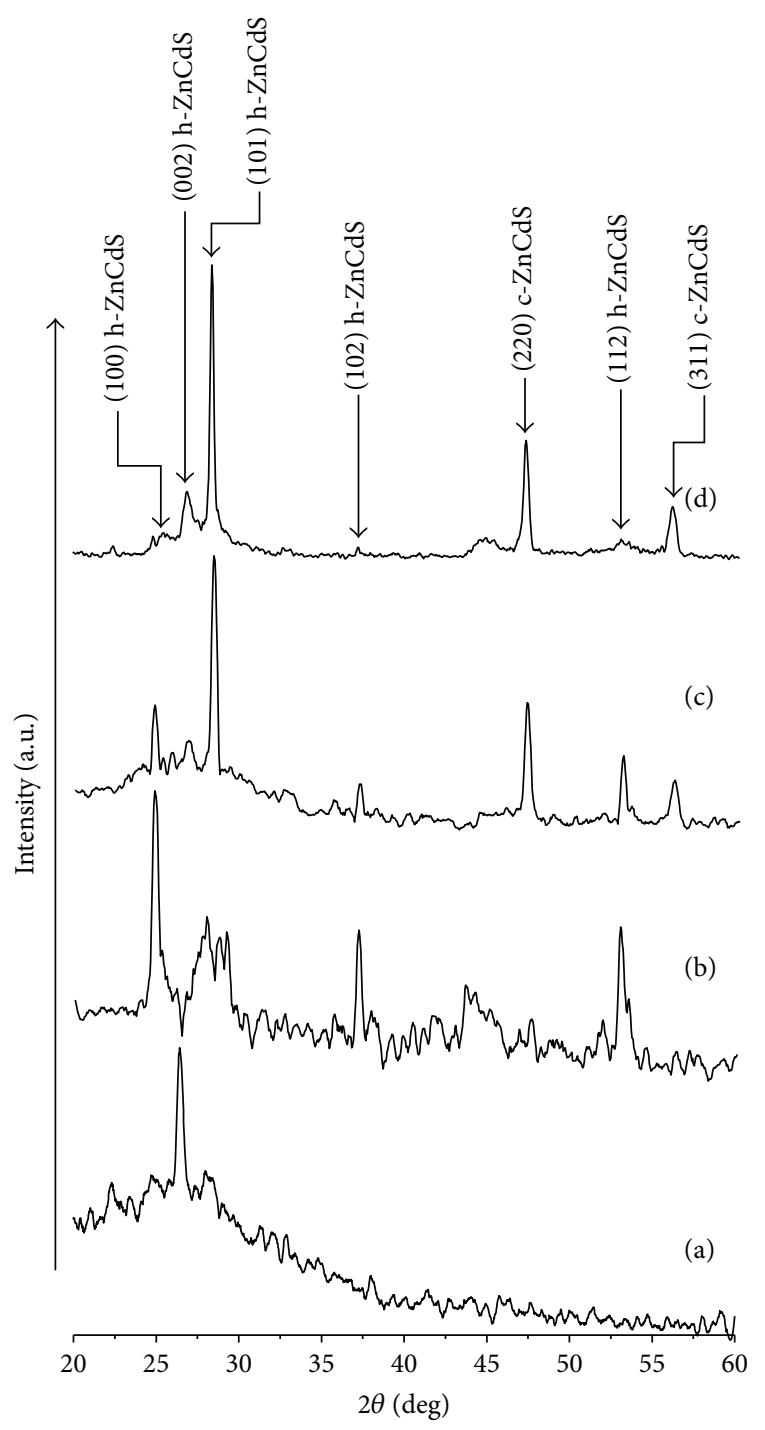

FIgURE 3: XRD patterns of ((a) and (b)) $4 \mathrm{~h} \mathrm{Zn}_{0.34} \mathrm{Cd}_{0.66} \mathrm{~S}$ and $\mathrm{Zn}_{0.81} \mathrm{Cd}_{0.19} \mathrm{~S}$ nanosheets, ((c) and (d)) $24 \mathrm{~h} \mathrm{Zn}_{0.7} \mathrm{Cd}_{0.3} \mathrm{~S}$ and $\mathrm{Zn}_{0.88} \mathrm{Cd}_{0.12} \mathrm{~S}$ nanosheets.

This complex has an organic-inorganic lamellar structure with inorganic $\mathrm{ZnCdS}$ sheets separated by organic en molecules that serve as bridge ligands between $\mathrm{Cd}$ and $\mathrm{Zn}$ atoms in the neighboring inorganic layers and prevent the sheets from aggregating and forming the ZnCdS bulk phase $[17,18]$. Wang et al. prepared $\mathrm{ZnCdS}$ nanowires by using solvothermal synthesis at $180^{\circ} \mathrm{C}$ for about $17 \mathrm{~h}$, stirring the solution continuously the whole time [4]. The EDS results suggest that the $\mathrm{Zn}$ ratio in the $\mathrm{Zn}_{x} \mathrm{Cd}_{1-x} \mathrm{~S}$ nanosheets increased with increasing $\mathrm{ZnCl}_{2}$ concentration as shown in the EDS spectra in Figure 2 and listed in Table 1. The crystalline structure was analyzed based on the XRD spectra shown in Figure 3. Diffraction peaks corresponding to the (100), (002), (101), (102), and (112) lattice planes of $\mathrm{ZnCdS}$ wurtzite were consistent with those found in the standard data (PDF-4, 00-005-7863). Further, two diffraction peaks appeared at 47.1 and $56^{\circ}$ in the spectra for the $24 \mathrm{~h}$ samples

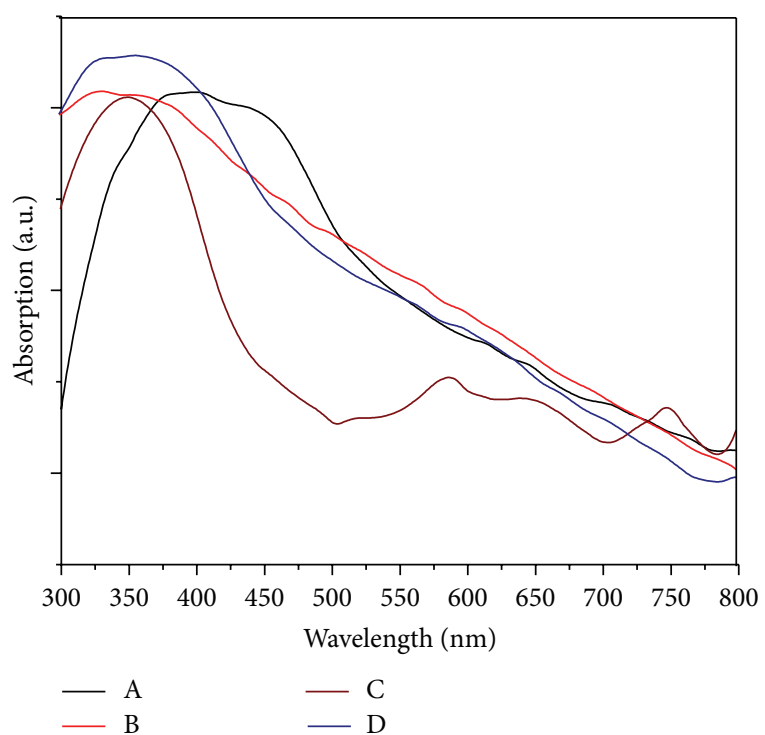

FIgURE 4: Absorbance of ((a) and (b)) $4 \mathrm{~h} \mathrm{Zn}_{0.34} \mathrm{Cd}_{0.66} \mathrm{~S}$ and $\mathrm{Zn}_{0.81} \mathrm{Cd}_{0.19} \mathrm{~S}$ nanosheets, ((c) and (d)) $24 \mathrm{~h} \mathrm{Zn}_{0.7} \mathrm{Cd}_{0.3} \mathrm{~S}$ and $\mathrm{Zn}_{0.88} \mathrm{Cd}_{0.12} \mathrm{~S}$ nanosheets.

and could be associated with the (220) and (311) orientations of the $\mathrm{ZnCdS}$ cubic phase (PDF-4, 00-005-3822). Moreover, the $24 \mathrm{~h} \mathrm{Zn}_{x} \mathrm{Cd}_{1-x} \mathrm{~S}$ nanosheets were more crystalline than the $4 \mathrm{~h}$ ones. The preferred growth orientation of the $4 \mathrm{~h}$ $\mathrm{Zn}_{0.34} \mathrm{Cd}_{0.66} \mathrm{~S}$ nanosheets was along the (002) direction, which changed to along the (100) direction for the $4 \mathrm{~h}$ $\mathrm{Zn}_{0.81} \mathrm{Cd}_{0.19} \mathrm{~S}$ nanosheets. The zinc ratio had no effect on the preferred growth orientations, along the (110) direction, of the $24 \mathrm{~h} \mathrm{Zn}_{0.7} \mathrm{Cd}_{0.3} \mathrm{~S}$ and $\mathrm{Zn}_{0.88} \mathrm{Cd}_{0.12} \mathrm{~S}$ nanosheets. The UV-vis absorption spectra for the 4 and $24 \mathrm{~h} \mathrm{Zn}_{x} \mathrm{Cd}_{1-x}$ S nanosheets with different $\mathrm{Zn}$ ratios are shown in Figure 5. The absorption edge originally at $459 \mathrm{~nm}$ blue-shifted to $362 \mathrm{~nm}$ for the $4 \mathrm{~h}$ samples when the $\mathrm{Zn}$ ratio increased from 0.34 to $0.81 \%$. The $24 \mathrm{~h}$ samples exhibited the same absorption behavior: the absorption edge originally at $379 \mathrm{~nm}$, when the $\mathrm{Zn}$ ratio was $0.7 \%$, blue-sifted to $350 \mathrm{~nm}$ for the $0.88 \% \mathrm{Zn}$ nanosheets. The optical band gap of the ternary $\mathrm{Zn}_{x} \mathrm{Cd}_{1-x} \mathrm{~S}$ compound can be estimated using Vegard's formula [19]:

$$
E_{g}(x)=E_{g}(\mathrm{CdS})+0.69 x+0.62 x^{2} .
$$

The optical band gaps measured for the prepared $\mathrm{Zn}_{x} \mathrm{Cd}_{1-x} \mathrm{~S}$ nanosheets were consistent with the band gaps estimated using Vegard's formula, as shown in Table 1. Figure 4 shows the room temperature photoluminescence (PL) spectra of the $\mathrm{Zn}_{x} \mathrm{Cd}_{1-x} \mathrm{~S}$ nanosheets prepared using different $\mathrm{Zn}$ ratios and reaction times. The spectrum for the $4 \mathrm{~h} \mathrm{Zn} \mathrm{n}_{0.34} \mathrm{Cd}_{0.66} \mathrm{~S}$ nanosheets had emission bands at 460 and $565 \mathrm{~nm}$ : the former corresponds to the intrinsic near-bandedge (NBE) emission (consistent with the optical band gap at this ratio), and the latter is a broad band possibly associated with extrinsic deep-level emission (DLE) [20]. The spectrum for the $4 \mathrm{~h} \mathrm{Zn}_{0.81} \mathrm{Cd}_{0.19} \mathrm{~S}$ nanosheets had two bands, one at 420 and another at $530 \mathrm{~nm}$. The spectrum for the $24 \mathrm{~h}$ nanosheets had stronger emission peaks than those for the 


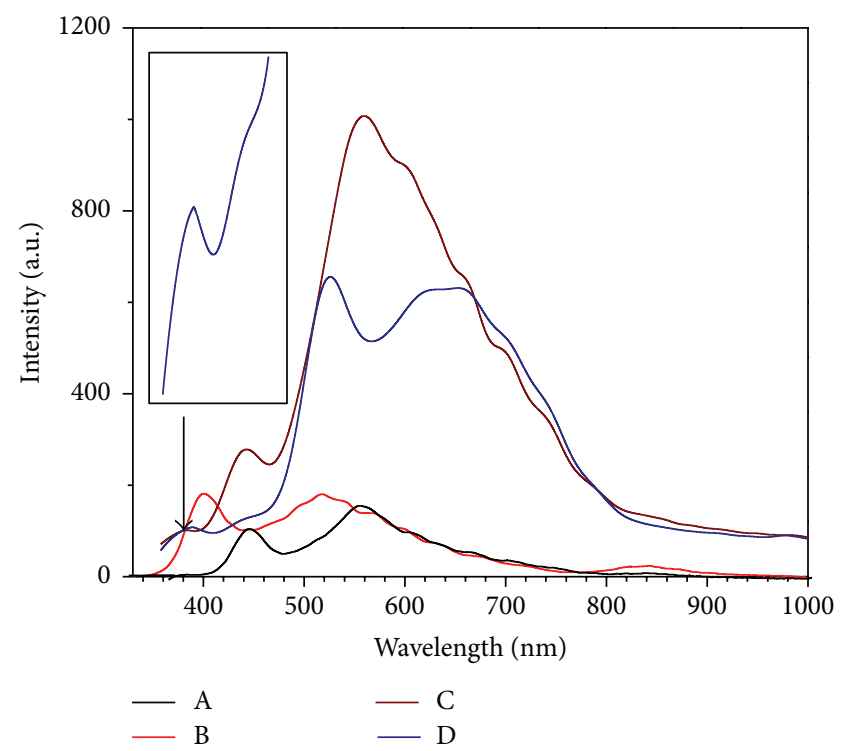

FIgURE 5: PL spectra of ((a) and (b)) $4 \mathrm{~h} \mathrm{Zn}_{0.34} \mathrm{Cd}_{0.66} \mathrm{~S}$ and $\mathrm{Zn}_{0.81} \mathrm{Cd}_{0.19} \mathrm{~S}$ nanosheets, ((c) and (d)) $24 \mathrm{~h} \mathrm{Zn}_{0.7} \mathrm{Cd}_{0.3} \mathrm{~S}$ and $\mathrm{Zn}_{0.88} \mathrm{Cd}_{0.12} \mathrm{~S}$ nanosheets.

$4 \mathrm{~h}$ nanosheets. The emission spectrum for the $\mathrm{Zn}_{0.7} \mathrm{Cd}_{0.3} \mathrm{~S}$ sample had two bands with peaks at 420 and $540 \mathrm{~nm}$, while that for the $\mathrm{Zn}_{0.88} \mathrm{Cd}_{0.12} \mathrm{~S}$ nanosheet had bands in the visible region with peaks at 507 and $630 \mathrm{~nm}$ as well as small peak located at $344 \mathrm{~nm}$. The broad emission band in visible region may correspond to the surface states of the nanosheet and/or lattice defects, such as vacancies or interstitial sulfur or $\mathrm{Zn}$ atoms. The shape and intensity of a band and its location in an emission spectrum depend on defect type concentration $[20,21]$. Zhao et al. [11] noted that the PL peak became increasingly blue-shifted with increasing $\mathrm{Zn}$ ratio in solvothermally synthesized $\mathrm{Zn}_{x} \mathrm{Cd}_{1-x} \mathrm{~S}$ nanocrystals.

\section{Conclusions}

$\mathrm{Zn}_{x} \mathrm{Cd}_{1-x} \mathrm{~S}$ nanosheets were prepared using solvothermal synthesis. The nanosheet dimensions increased when the reaction time was increased to $24 \mathrm{~h}$. Analysis of the crystalline structures indicated that the sheets had a hexagonal phase and that crystallinity increased as the reaction time was increased from 4 to $24 \mathrm{~h}$. Furthermore, the preferred growth orientation of the nanosheets depended on the $\mathrm{Zn}$ ratio and the reaction time. The optical band gap of the $\mathrm{Zn}_{x} \mathrm{Cd}_{1-x} \mathrm{~S}$ increased with increasing $\mathrm{Zn}$ ratio. The PL spectra of the prepared nanosheets show that the $24 \mathrm{~h}$ nanosheets had higher emission intensities than the $4 \mathrm{~h}$ nanosheets. Band emissions related to intrinsic near-band-edge emission and extrinsic deep-level emissions were observed. The locations of the emission bands depended on the $\mathrm{Zn}$ ratios and reaction times.

\section{Acknowledgments}

The authors gratefully acknowledge the support from ERGS grant and University Sains Malaysia.

\section{References}

[1] J. J. Hassan, Z. Hassan, and H. Abu-Hassan, "High-quality vertically aligned $\mathrm{ZnO}$ nanorods synthesized by microwaveassisted CBD with ZnO-PVA complex seed layer on Si substrates," Journal of Alloys and Compounds, vol. 509, no. 23, pp. 6711-6719, 2011.

[2] M. A. Mahdi, J. J. Hassan, S. S. Ng, and Z. Hassan, "Growth of CdS nanosheets and nanowires through the solvothermal method," Journal of Crystal Growth, vol. 359, pp. 43-48, 2012.

[3] H. F. Al-Taay, M. A. Mahdi, D. Parlevliet, Z. Hassan, and P. Jennings, "Preparation and characterization of silicon nanowires catalyzed by aluminum," Physica E, vol. 48, pp. 21-28, 2013.

[4] L. Wang, Y. Jiang, C. Wang et al., "Composition-controllable synthesis and optical properties of non-integral stoichiometry compound $\mathrm{Zn}_{x} \mathrm{Cd}_{1-x} \mathrm{~S}$ nanorods," Journal of Alloys and Compounds, vol. 454, no. 1-2, pp. 255-260, 2008.

[5] M. A. Mahdi, J. J. Hassan, Z. Hassan, and S. S. Ng, "Growth and characterization of $\mathrm{Zn}_{x} \mathrm{Cd}_{1-x} \mathrm{~S}$ nanoflowers by microwaveassisted chemical bath deposition," Journal of Alloys and Compounds, vol. 541, pp. 227-233, 2012.

[6] M. A. Mahdi, Z. Hassan, S. S. Ng, J. J. Hassan, and S. K. M. Bakhori, "Structural and optical properties of nanocrystalline CdS thin films prepared using microwave-assisted chemical bath deposition," Thin Solid Films, vol. 520, no. 9, pp. 3477-3484, 2012.

[7] P. Kumar, A. Misra, D. Kumar, N. Dhama, T. P. Sharma, and P. N. Dixit, "Structural and optical properties of vacuum evaporated $\mathrm{Cd}_{x} \mathrm{Zn}_{1-x} \mathrm{~S}$ thin films," Optical Materials, vol. 27, no. 2, pp. 261264, 2004.

[8] M. C. Baykul and N. Orhan, "Band alignment of $\mathrm{Cd}_{(1-x)} \mathrm{Zn}_{x} \mathrm{~S}$ produced by spray pyrolysis method," Thin Solid Films, vol. 518, no. 8, pp. 1925-1928, 2010.

[9] S. M. Zhou, "Fabrication and optical properties of Sb-doped CdS nanowires," Materials Letters, vol. 61, no. 1, pp. 119-122, 2007.

[10] M. A. Rafea, A. A. M. Farag, and N. Roushdy, "Structural and optical characteristics of nano-sized structure of $\mathrm{Zn}_{0.5} \mathrm{Cd}_{0.5} \mathrm{~S}$ thin films prepared by dip-coating method," Journal of Alloys and Compounds, vol. 485, no. 1-2, pp. 660-666, 2009.

[11] K. S. Zhao, L. Jia, X. Li, and J. Mu, "Preparation of quasimonodispersed $\mathrm{Cd}_{x} \mathrm{Zn}_{1-x} \mathrm{~S}$ nanocrystals and their optical properties," Colloids and Surfaces A, vol. 398, pp. 48-53, 2012.

[12] Y. Xi, C. Hu, C. Zheng, H. Zhang, R. Yang, and Y. Tian, "Optical switches based on CdS single nanowire," Materials Research Bulletin, vol. 45, no. 10, pp. 1476-1480, 2010.

[13] L. Yingkai, Z. Xiangping, H. Dedong, and W. Hui, "The photoconductance of a single CdS nanoribbon," Journal of Materials Science, vol. 41, no. 19, pp. 6492-6496, 2006.

[14] Q.H. Li, T. Gao, and T. H. Wang, "Optoelectronic characteristics of single CdS nanobelts," Applied Physics Letters, vol. 86, no. 19, pp. 193109-[193112, 2005.

[15] M. A. Mahdi, J. J. Hassan, S. S. Ng, and Z. Hassan, "Synthesis and characterization of single-crystal CdS nanosheet for highspeed photodetection," Physica E, vol. 44, no. 7-8, pp. 1716-1721, 2012.

[16] P. Dalvand, M. R. Mohammadi, and D. J. Fray, "One-dimensional cadmium sulfide (CdS) nanostructures by the solvothermal process: controlling crystal structure and morphology aided by different solvents," Materials Letters, vol. 65, no. 9, pp. 1291-1294, 2011. 
[17] S. Kar, S. Santra, and H. Heinrich, "Fabrication of high aspect ratio core-shell CdS-Mn/ZnS nanowires by a two step solvothermal process," Journal of Physical Chemistry C, vol. 112, no. 11, pp. 4036-4041, 2008.

[18] X. Wang and Y. Li, "Solution-based synthetic strategies for 1-D nanostructures," Inorganic Chemistry, vol. 45, no. 19, pp. 75227534, 2006.

[19] M. A. Mahdi and S. K. J. Al-Ani, "Structural and optical properties of chemical deposition CdS thin films," International Journal of Nanoelectronics and Materials, vol. 5, pp. 11-24, 2012.

[20] Y. Y. Xi, L. Y. C. Teresa, and H. L. N. Dickon, "Synthesis of ternary $\mathrm{Zn}_{x} \mathrm{Cd}_{1-x} \mathrm{~S}$ nanowires by thermal evaporation and the study of their photoluminescence," Materials Letters, vol. 62, no. 1, pp. 128-132, 2008.

[21] X. He and L. Gao, "One solvent, one pot and free capping ligands: synthesis of alloyed multipod-branched $\mathrm{Cd}_{x} \mathrm{Zn}_{1-x} \mathrm{~S}$ nanocrystals," Journal of Colloid and Interface Science, vol. 349, no. 1, pp. 159-165, 2010. 

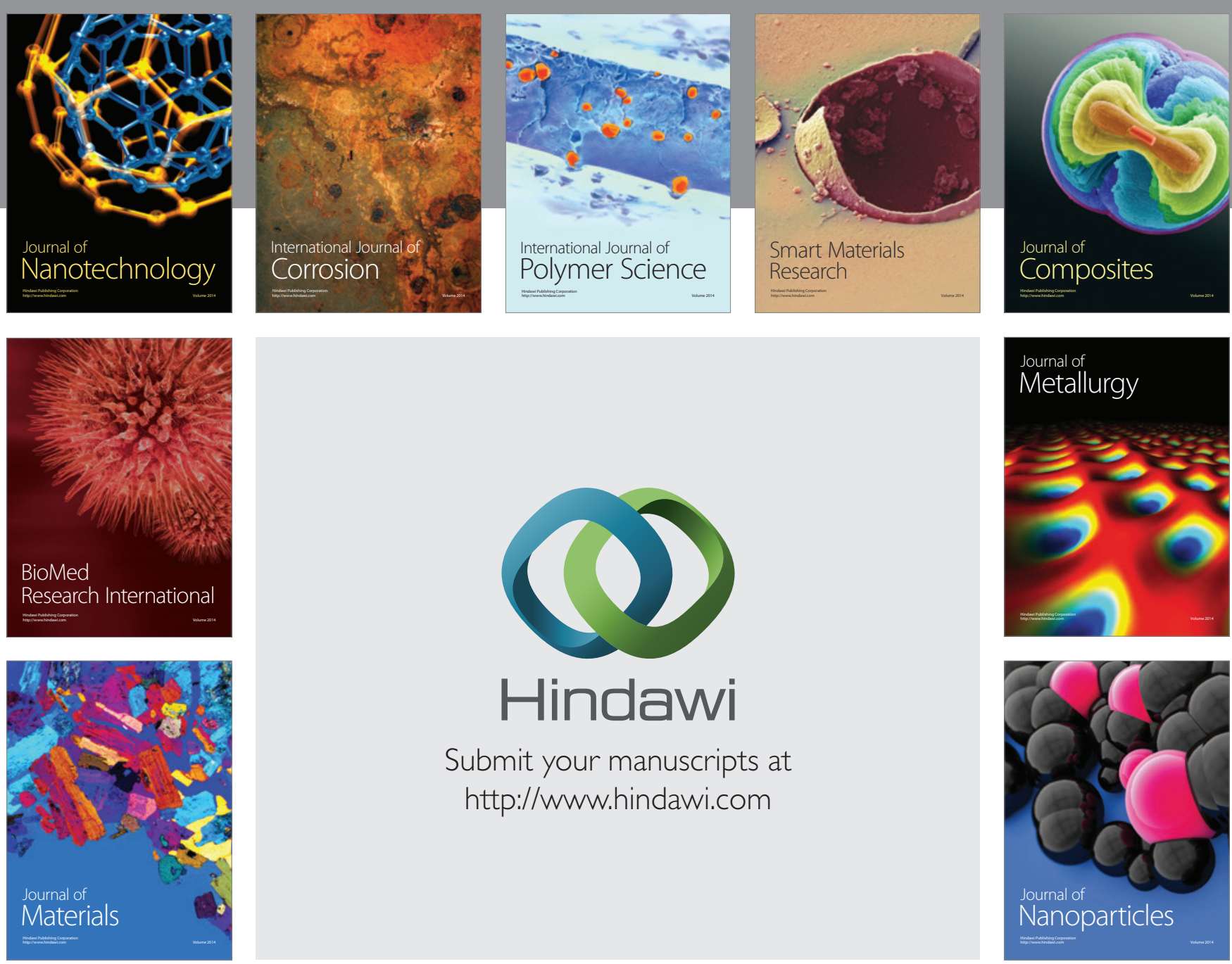

Submit your manuscripts at http://www.hindawi.com
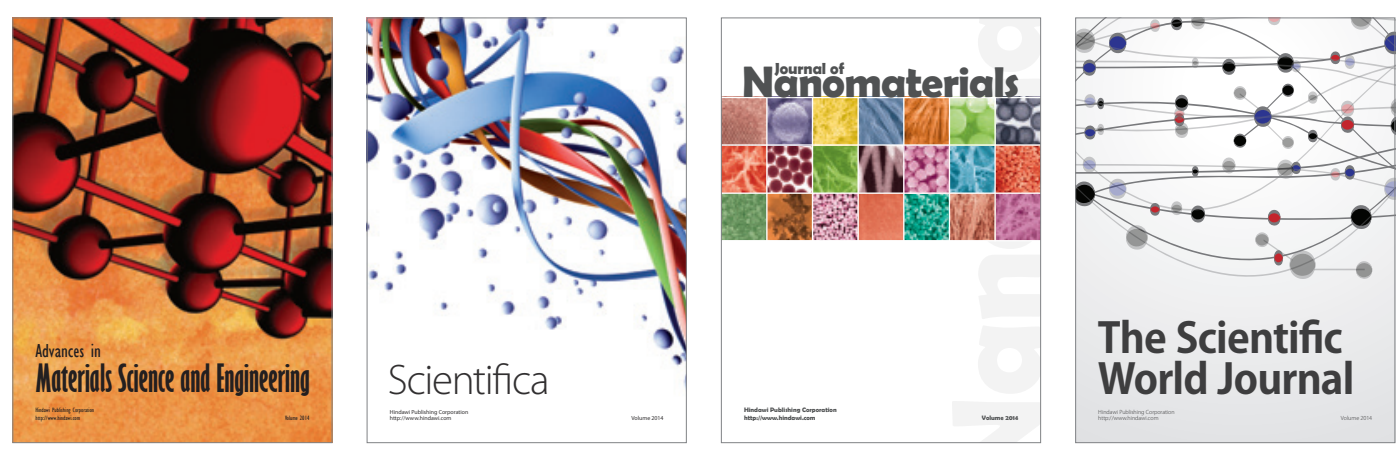

\section{The Scientific World Journal}
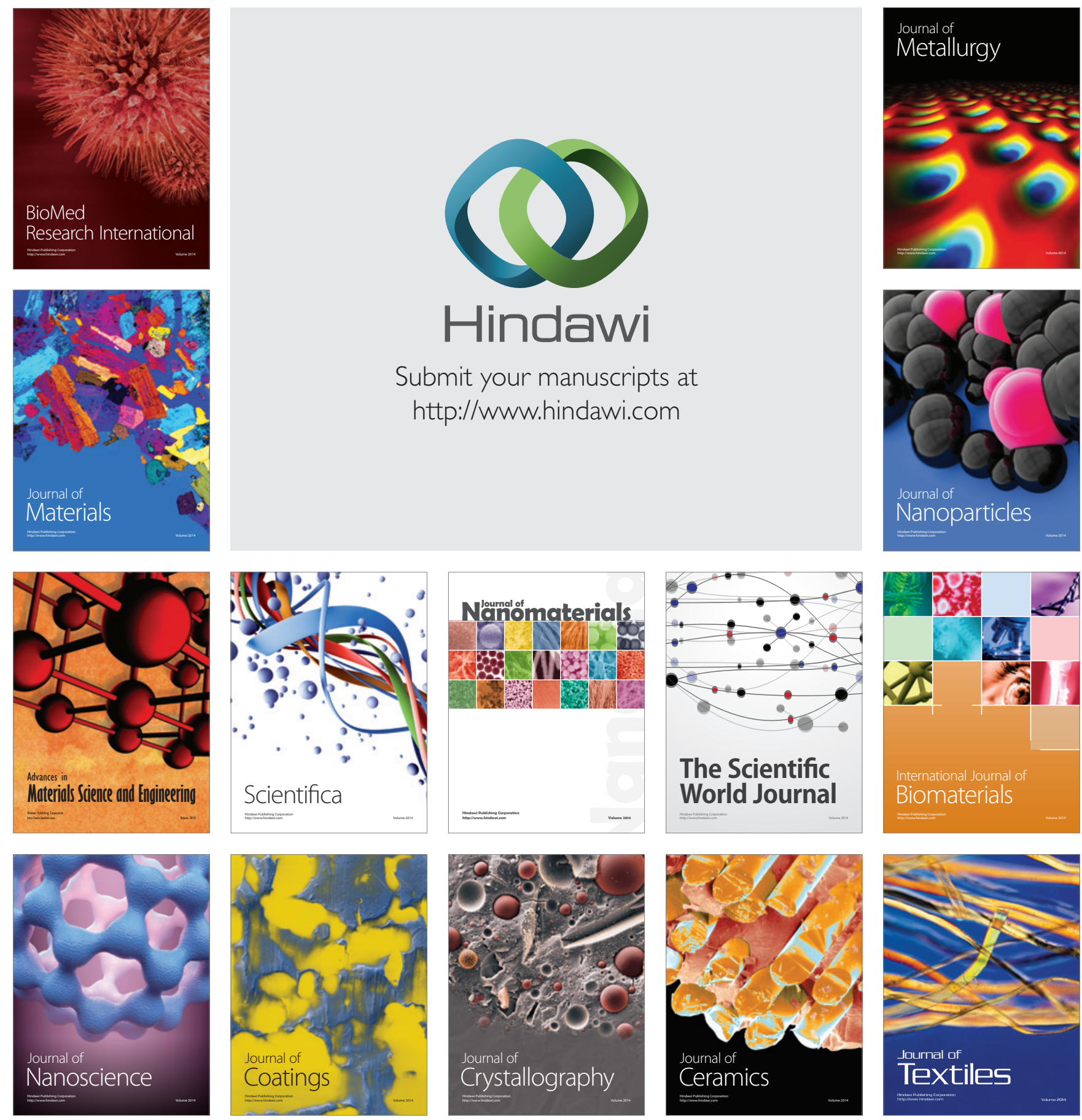